\title{
Maxey-Eakin Methods for Estimating Groundwater Recharge in the Fenner Watershed, Southeastern, California
}

M.L. Davisson and T.P. Rose

Lawrence Livermore National Laboratory

May 15, 2000 


\section{DISCLAIMER}

This document was prepared as an account of work sponsored by an agency of the United States Government. Neither the United States Government nor the University of California nor any of their employees, makes any warranty, express or implied, or assumes any legal liability or responsibility for the accuracy, completeness, or usefulness of any information, apparatus, product, or process disclosed, or represents that its use would not infringe privately owned rights. Reference herein to any specific commercial product, process, or service by trade name, trademark, manufacturer, or otherwise, does not necessarily constitute or imply its endorsement, recommendation, or favoring by the United States Government or the University of California. The views and opinions of authors expressed herein do not necessarily state or reflect those of the United States Government or the University of California, and shall not be used for advertising or product endorsement purposes.

Work performed under the auspices of the U. S. Department of Energy by the University of California Lawrence Livermore National Laboratory under Contract W-7405-Eng-48.

This report has been reproduced directly from the best available copy.

Available to DOE and DOE contractors from the

Office of Scientific and Technical Information

P.O. Box 62, Oak Ridge, TN 37831

Prices available from (423) 576-8401

http://apollo.osti.gov/bridge/

Available to the public from the National Technical Information Service

U.S. Department of Commerce 5285 Port Royal Rd., Springfield, VA 22161 http://www.ntis.gov/

OR

Lawrence Livermore National Laboratory Technical Information Department's Digital Library http://www.llnl.gov/tid/Library.html 
Maxey-Eakin Methods for Estimating Groundwater Recharge in the Fenner Watershed, Southeastern, California.

\author{
M.L. Davisson \\ Health and Ecological Assessment Division \\ T.P. Rose \\ Analytical and Nuclear Chemistry Division
}




\begin{abstract}
Recent review comments by the U.S. Geological Survey, Water Resources Division on the Cadiz Groundwater Storage and Dry-Year Supply Program Draft Environmental Planning Report were accompanied by an independent recharge estimate to the Fenner Basin based on a Maxey-Eakin method. The following report has analyzed WRD's recharge estimates and concludes that those results greatly underestimate annual recharge and lack credibility. Among the reasons outlined are 1) WRD's lack of geographic scale and context when analyzing precipitation-elevation data, 2) WRD's use of an uncalibrated Maxey-Eakin model, and 3) WRD's lack of direct observational experience in the eastern Mojave-Fenner Basin region. This report presents a more exhaustive analysis of data, supported by direct field observations, and estimates recharge using a calibrated Maxey-Eakin model. This report concludes that the possible range in annual groundwater replenishment rates to the Fenner Basin are between 7864 acre-ft and 29,185 acre-ft. The lower limit is a worst-case-scenario. This range is consistent with original recharge estimates calculated and presented in the Cadiz Groundwater Storage and Dry-Year Supply Program Draft Environmental Planning Report.
\end{abstract}

\title{
Introduction
}

As part of a drought mitigation strategy and long-term planning for beneficial use of imported Colorado River water, the Metropolitan Water District (MWD) of southern California investigated the feasibility of storing river water in groundwater aquifers of the eastern Mojave Desert. This effort has culminated in the production and public release of the Cadiz Groundwater Storage and Dry-Year Supply Program Draft Environmental Planning Report, Groundwater Resources, Volumes I and II (Draft EIR). In particular, MWD and Cadiz Inc. contracted to Geosciences Support Services Inc. to perform pilot percolation studies, groundwater modeling, and precipitation/runoff analysis in the Fenner groundwater basin, which overlies the proposed storage site (Fig. 1). The project proposes to store and withdrawal Colorado River water over a 50-year period. During periods of groundwater withdrawal, MWD is committed to not exceed the natural replenishment rates of the groundwater basin. As part of a plan to insure that this will not happen, several independent analyses were conducted to estimate the rates of natural groundwater replenishment to the Fenner Groundwater Basin, which was included in the Draft EIR.

During the public comment period for the Draft EIR, the U.S. Geologic Survey, Water Resources Division (WRD) officially submitted comments. It was their conclusion that the natural groundwater replenishment rates calculated for the Draft EIR were too high. In the WRD review, they provided an independent recharge calculation based on a Maxey-Eakin estimation approach.

The authors of this current report, under the auspices of Lawrence Livermore National Laboratory (LLNL), were asked to provide an analysis of WRD's Maxey-Eakin estimation. It is the conclusion of this report, that the recharge estimate by the WRD is unreasonably low. Their low estimate was due to 1) inadvertent exclusion of key data and underestimation of local precipitation, 2) underestimation of local groundwater recharge rates, and 3) use of an un-calibrated Maxey-Eakin recharge model. 


\section{Estimation of Annual Rainfall by WRD}

The basic premise of a Maxey-Eakin recharge estimate is that the rate of groundwater replenishment is proportional to the annual rainfall. The method is best suited for arid environments, where high elevations typically experience much greater annual rainfall than low elevations. Recharge estimates using a Maxey-Eakin method requires predicting how precipitation (rain and snow) varies with elevation change on an annual basis in localized areas. From these data, a percentage of annual precipitation will contribute to groundwater recharge. Hence, a Maxey-Eakin model predicts recharge as a function of precipitation.

For the Fenner Basin a reasonable approach would be to plot mean annual precipitation data against its elevation collected at relevant sites. A curve can be fitted to this data to provide a quantitative means to calculate annual precipitation at various elevations. Note that the higher the slope on a precipitation-elevation curve, the higher the groundwater recharge estimate. However, previous attempts to create precipitation-elevation curves in western Nevada have been difficult and result in large uncertainty (for example, see Hevesi et al., 1992, and references therein).

In WRD's review comments on the Draft EIR, they presented a precipitation-elevation plot that included a variety of data points from southeastern California (Fig. 2). It should be noted that the data they selected does not represent the entire range of elevations contributing to groundwater recharge in the Fenner basin. In particular, their data only includes points less than 1500 meters elevation, however, the Providence and New York mountains in the Fenner basin both exceed 2000 meters. Although data from these sites do not exist, their ultimate exclusion will contribute to erroneous results.

In the WRD analysis of their data, they separated from the database four points that were in close proximity to the Fenner basin. They "visually" fitted an independent curve to these four points and a mathematical curve to the remainder of the database. In the case of the four data points, the slope of the curve was much higher than the curve fitted to the remainder of the data. WRD concluded that the higher slope was "unrealistic", but provided no evidence to support this conclusion. Subsequently, they favored the lower slope fitted to the remainder of the data even though these data are farther from the Fenner basin and show considerable scatter around the fitted curve.

\section{Estimation of Annual Rainfall by LLNL}

Several environmental factors complicate the distribution of rainfall throughout southeastern California and western Nevada. For example, the Sierra Nevada, San Gabriel, and San Bernadino mountains create a dramatic rain shadow effect that limits annual rainfall the east. In addition, winter storms originating from the Pacific Ocean have different trajectories and can produce locally intense snow and/or rain, but exclude other areas depending on its path. Furthermore, summer storms originating from the Gulf of California produce more annual precipitation in the eastern Mojave Desert, but much less in the western Mojave. In order to predict the annual precipitation as a function of elevation, the mechanisms that control the geographic distribution must be understood in 
the context of these complications. In addition, the appropriate geographic scale needs to be represented in any data analysis, for which the WRD's data analysis lacks.

The strongest effect on annual precipitation in southeastern California and western Nevada is the rain shadow caused by the Sierra Nevada Mountains. The rain shadow effect will have its greatest intensity just east of the Sierra Nevada, and decrease in an eastward direction. The contribution of this effect extends eastward into Central Nevada. Therefore, the appropriate scale to understand the mechanism of rainfall distribution in southeastern California should include data from a large part of Nevada. Consequently, the relationship between annual precipitation and elevation should be controlled by eastwest direction, or longitudinal position. This relationship has been recognized and documented by previous researchers, including the U.S. Geologic Survey, WRD (Winograd and Thordarson, 1975; see page C6 and references therein).

Below we plot annual precipitation and elevation data for weather stations throughout southeastern California and western to southern Nevada (Fig. 3; Table 1). This plot includes more data than used in the WRD analysis (Fig. 2), and unlike the WRD plot, it includes elevations in excess of 2000 meters. Like the WRD's plot, figure 3 isolates the same four data points in close proximity to the Fenner Basin, for which a mathematical curve has been fitted to the data. In addition, figure 3 separates the data into two groups: those data collected west of $116^{\circ} \mathrm{W}$ longitude, and those collected east of $116^{\circ} \mathrm{W}$. This grouping of the data demonstrates an important east-west dependence on how annual precipitation varies as a function of elevation. In particular, those data closer to the Sierra Nevada (e.g. Western Mojave Desert) have significantly less annual precipitation at higher elevations than further east. The $116^{\circ} \mathrm{W}$ demarcation was used because it approximately coincides with a low elevation trend extending south from the Salton Sea trough and north toward Hot Creek Valley in Central Nevada. Prominent high elevation areas such as the Fenner watershed and the Spring Mountains lie east of $116^{\circ} \mathrm{W}$, while the San Bernadino Mts., the Sierra Nevada, and the White Mts. lie to the west.

Mathematical curves fit to these two data groups, using an exponential function, shows an increasing slope with increasing distance from the Sierra Nevada. The quality of these curve fits is also good with $\mathrm{R}^{2}$ regressions from 0.66 to 0.68 . In addition, a curve was also fitted to the four data points used by the WRD for stations in the Fenner basin area. The curve fit for these data yielded a much higher slope, and predicts significantly higher precipitation rates at higher elevation.

The curve fit to data east of $116^{\circ} \mathrm{W}$ longitude illustrates the regional precipitation/elevation effect, which is given the term "regional curve". The Fenner Basin is a local area residing in this regional group. The regional curve describes the precipitation/elevation effect at a larger scale. At smaller scales (i.e. Fenner Basin), local curves with higher and lower slopes occur, that combined together form the regional curve. In figure 3, the four data points for the Fenner Basin area is one such example of a local curve. In this case, the four points form a higher slope than the regional curve, and represent the local, small-scale effect. Therefore, WRD's conclusion that the higher slope formed by the four points is "unrealistic" is not correct, but rather on the contrary, this 
local curve more accurately reflects local conditions. It is, therefore, appropriate to use the steeper curve in figure 3 to calculate recharge to the Fenner basin. It is most appropriate to use the regional curve to calculate recharge to a larger, more regional area. Applying the regional curve to a local basin such as the Fenner Basin is an inappropriate matching of scales.

In figure 3 , the curve fitted to data west of $116^{\circ} \mathrm{W}$ longitude demonstrates that for the western Mojave Desert the rate of precipitation with respect to elevation is far lower than in the eastern Mojave. This implies that recharge rates are significantly lower in the western Mojave than in the eastern Mojave. Almost all of WRD's experience on desert groundwater recharge is in the western Mojave Desert (see Fig. 1), as evident in their review comments and their consistent referral to that work. Based on figure 3, however, WRD's knowledge of western Mojave Desert groundwater is not translatable to the eastern Mojave, and these groundwater systems are not analogous by virtue of their different climate.

\section{Scientific Basis for the Maxey-Eakin Method}

The Maxey-Eakin method requires determination of both a precipitation rate and a recharge rate. Precipitation rates were estimated as a function of elevation (Fig. 3). Groundwater replenishment rates are estimated on the basis that some fraction of annual precipitation will recharge, and that fraction will increase with increasing elevation (Maxey and Eakin, 1949). This results in a hypothetical curve relating annual groundwater recharge to annual precipitation (Fig. 4)

Field validation of recharge rates is critical in order to establish credibility to any estimate. This is due to the fact that the Maxey-Eakin approach is empirical. An empirical model is derived from practical experience rather than basic theory. Therefore, a validated Maxey-Eakin model in one groundwater basin does not necessarily translate to a different one.

In the WRD's Maxey-Eakin model, they used a curve previously calibrated to three separate locations in western Nevada and applied it to the Fenner Basin (see Fig. 1). It is of particular importance to note that all three of the WRD's locations are west of longitude $116^{\circ} \mathrm{W}$. As shown in an accompanying report, annual precipitation west of $116^{\circ} \mathrm{W}$ is significantly lower than east of $116^{\circ} \mathrm{W}$. Therefore, the WRD's Maxey-Eakin curve was calibrated to a drier climate, and its application to the Fenner Basin lacks credibility.

\section{Recharge Rates in the Fenner Watershed}

As part of LLNL's analysis, a new Maxey-Eakin curve was developed using four independent field observations in the Fenner Basin (Fig. 4). Recharge rates to these four sites were determined by a hydrologic mass balance method, for which three of the sites have been calibrated to groundwater age dates. Detailed discussions of each calibration point are presented in the Appendix. 
As can be seen in figure 4, the Maxey-Eakin curve developed for the Fenner Basin predicts significantly higher recharge rates than would be predicted by the WRD's curve. The differences in the two curves is expected since the Maxey-Eakin model is empirical and results will vary significantly between different geographic settings and between different geographic scales. The Fenner Basin curve is calibrated to field observation within project area basin, whereas the WRD's curve was calibrated outside the project area, at a larger scale, and in drier climates north and west of the Fenner Basin (Fig. 1).

\section{LLNL Maxey-Eakin Recharge Estimates}

Maxey-Eakin recharge estimates in the Fenner Basin require computing surface area as a function of elevation. These results are tabulated in Table 1 and were generated by digital methods. Average annual precipitation is then computed over the elevation range and is also presented in Table 1. Two precipitation-elevation curves were used: 1) the regional curve based on weather stations east of $116^{\circ} \mathrm{W}$ longitude in southeastern California and southern Nevada; 2) the local curve based on four stations nearby or within the Fenner Basin (Fig. 3). These curves encompass the possible range in annual precipitation in the Fenner Basin. However, the local curve is more relevant to the Fenner Basin due to its close proximity and its similar geographic scale.

The percent of annual precipitation that contributes to groundwater recharge is estimated from the Maxey-Eakin curve (Fig. 4). The Fenner Basin curve is used since it has been calibrated to four separate locations within the basin. No data exists on this curve for precipitation rates exceeding $380 \mathrm{~mm} / \mathrm{yr}$. Therefore, a line is joined between the upper point of the Fenner Basin curve and the upper point of the WRD curve, which is used as an estimate of annual recharge for areas with precipitation rates exceeding $380 \mathrm{~mm} / \mathrm{yr}$. However, the data points forming the Fenner Basin curve are linear over the range of observation and are used for all other recharge estimates.

The sum of annual recharge computed over the elevation range in Fenner Basin is presented in Table 1. The recharge rate is 16,214 acre- $\mathrm{ft}$ using the regional precipitationelevation curve, and is 29,185 acre-ft using the local curve. Based on the methods and the available data, the 29,185 acre-ft estimate is a maximum recharge rate. However, assumptions used to calibrate the Maxey-Eakin curve for the Fenner Basin were based on conservative parameters (see Appendix). Therefore, the maximum recharge rate could still be higher than 29,185 acre-ft per year.

In Maxey-Eakin's original paper on recharge estimates (Maxey and Eakin, 1949), they assumed that no recharge occurred in areas receiving less than $200 \mathrm{~mm} / \mathrm{yr}(8 \mathrm{in} / \mathrm{yr})$ of precipitation. Although supporting evidence is lacking for this assumption, this report attempts to honor this notion by recalculating the annual recharge estimates in Table 1 and eliminating all potential recharge for areas less than $200 \mathrm{~mm} / \mathrm{yr}$. This results in revised recharge estimates of 7864 acre-ft per year using the regional precipitationelevation curve and 23,511 acre-ft using the local curve. Note that in eliminating areas of less than $200 \mathrm{~mm} / \mathrm{yr}$ precipitation, the annual recharge is still well within the range estimated by independent approaches outline in the Draft EIR. 
In a risk-based analysis of the proposed groundwater storage project in Fenner Basin, the upper and lower limits of annual recharge are needed to assess potential environmental impacts. Based on the evidence and data analysis presented in this report, the possible range in annual recharge to the Fenner Basin is 7864 to 29,185 acre-ft per year. Based on the analysis, the lower limit of 7864 acre-ft is a worse-case-scenario, and annual recharge is likely higher.

The results of the LLNL Maxey-Eakin recharge estimates for the Fenner Basin differ greatly from those estimated by WRD in their review comments. They suggested recharge was between 2070 and 10,343 acre-ft per year for the Fenner Basin. They suggested the higher recharge rate was "unrealistic". However, their analysis and recharge estimate lacked 1) the geographic context set forth in this report, 2) a calibrated Maxey-Eakin curve, and 3) direct observational experience in the Fenner Basin. In their review comments, the WRD presented an interpretation that recharge rates should be low in the Fenner Basin. That interpretation was based on WRD's independent observations in the western Mojave Desert. As pointed out in this report, such comparisons lack credibility because of significant climate variability between the eastern and western Mojave Deserts.

This work was performed under the auspices of the U.S. Department of Energy by University of California Lawrence Livermore National Laboratory under contract No. W-7405-Eng-48.

\section{References}

Hevesi, J.A., Istok, J.D., Flint, A.L., 1992, Precipitation estimation in mountainous terrain using multivariate geostatistics. Part I. Structural analysis. Jour. Appl. Meteorol., 31, 661-676.

Maxey, G.B. and Eakin, T.E., 1949, Groundwater in the White River Valley, White Pine, Nye, and Lincoln counties, Nevada. Water Resources Bulletin No. 8, State of Nevada, Office of the State Engineer.

Winograd, I.J. and Thordarson, W., 1975, Hydrogeologic and hydrochemical framework, south-central Great Basin, Nevada-California, with special reference to the Nevada Test Site. U.S. Geol. Surv. Prof. Paper 712-C. 126 pgs. 
Calibration

Points for

WRD's Maxey-

Eakin Model

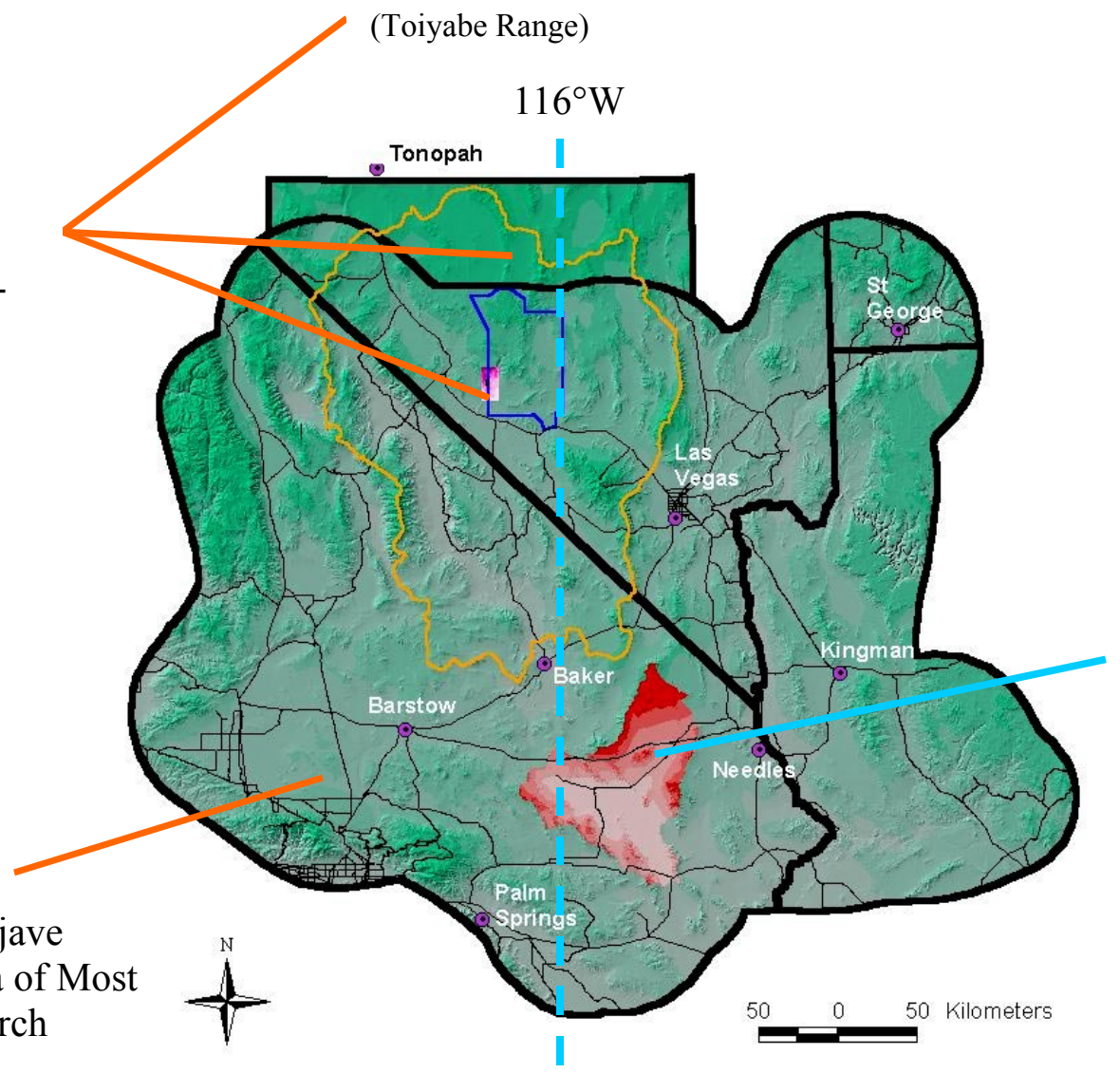

Fenner

Basin

Western Mojave

Desert (Area of Most

WRD Research Experience)

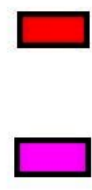

Cadiz Project
Study Basin

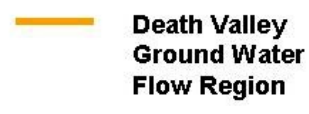

Yucca Mountain Study Site

Nevada
Test Site

Figure 1. Proposed groundwater storage area is in the Fenner Basin. 


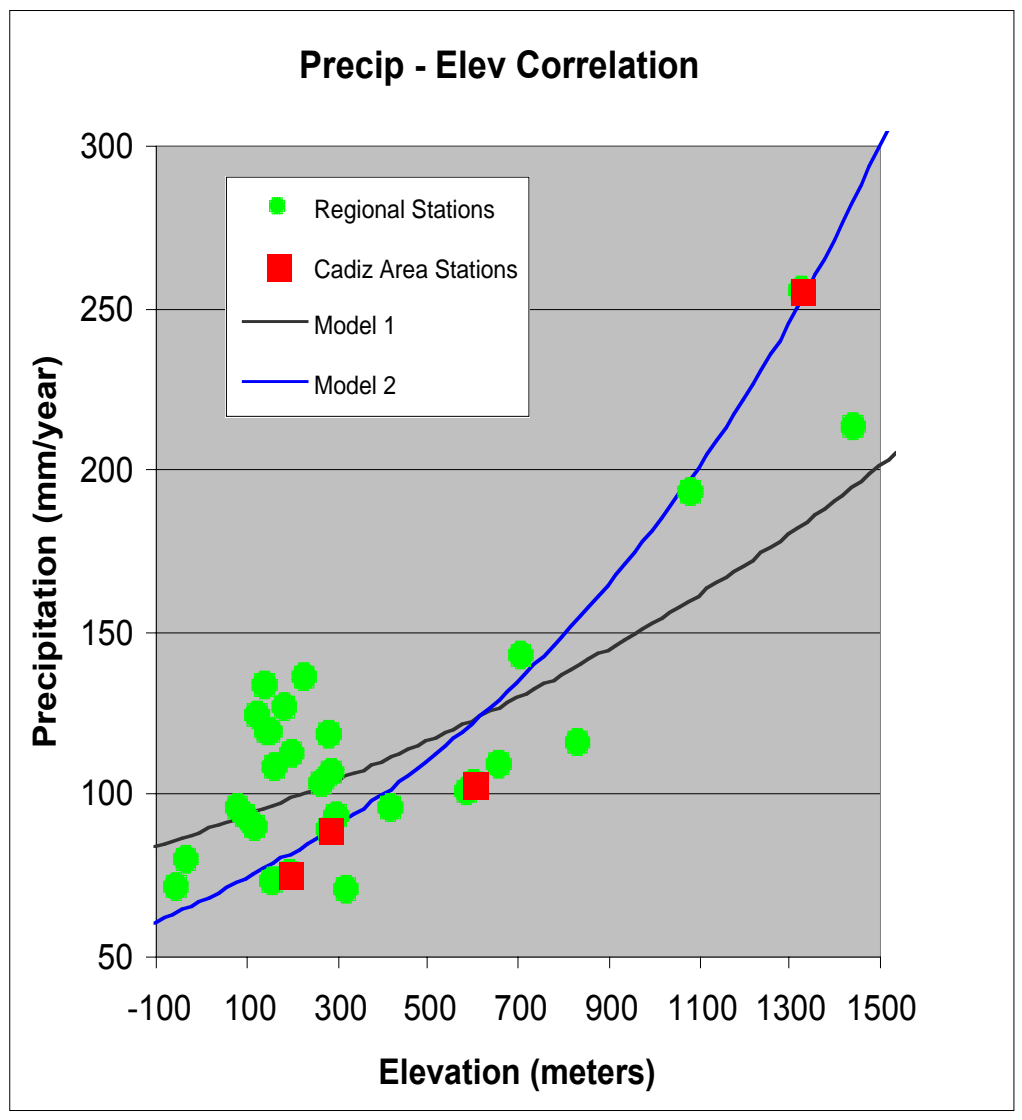

Figure 2. WRD's precipitation-elevation curves. 


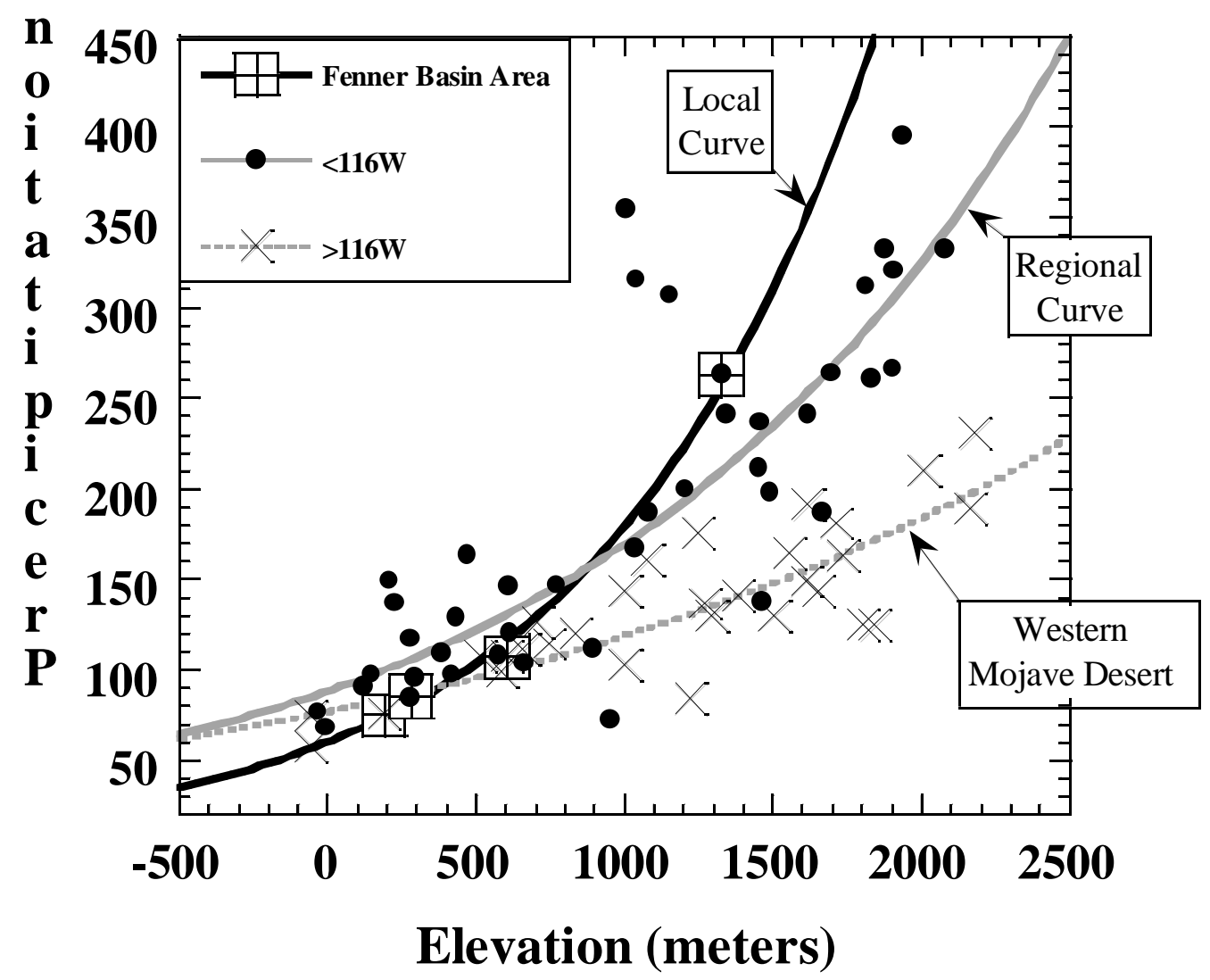

Figure 3. LLNL's precipitation-elevation curves.

Regional curve: $\mathrm{y}=88.6 * \mathrm{e}^{0.00065 \mathrm{x}}$

Local curve: $\quad \mathrm{y}=60.1 * \mathrm{e}^{0.0011 \mathrm{x}}$ 


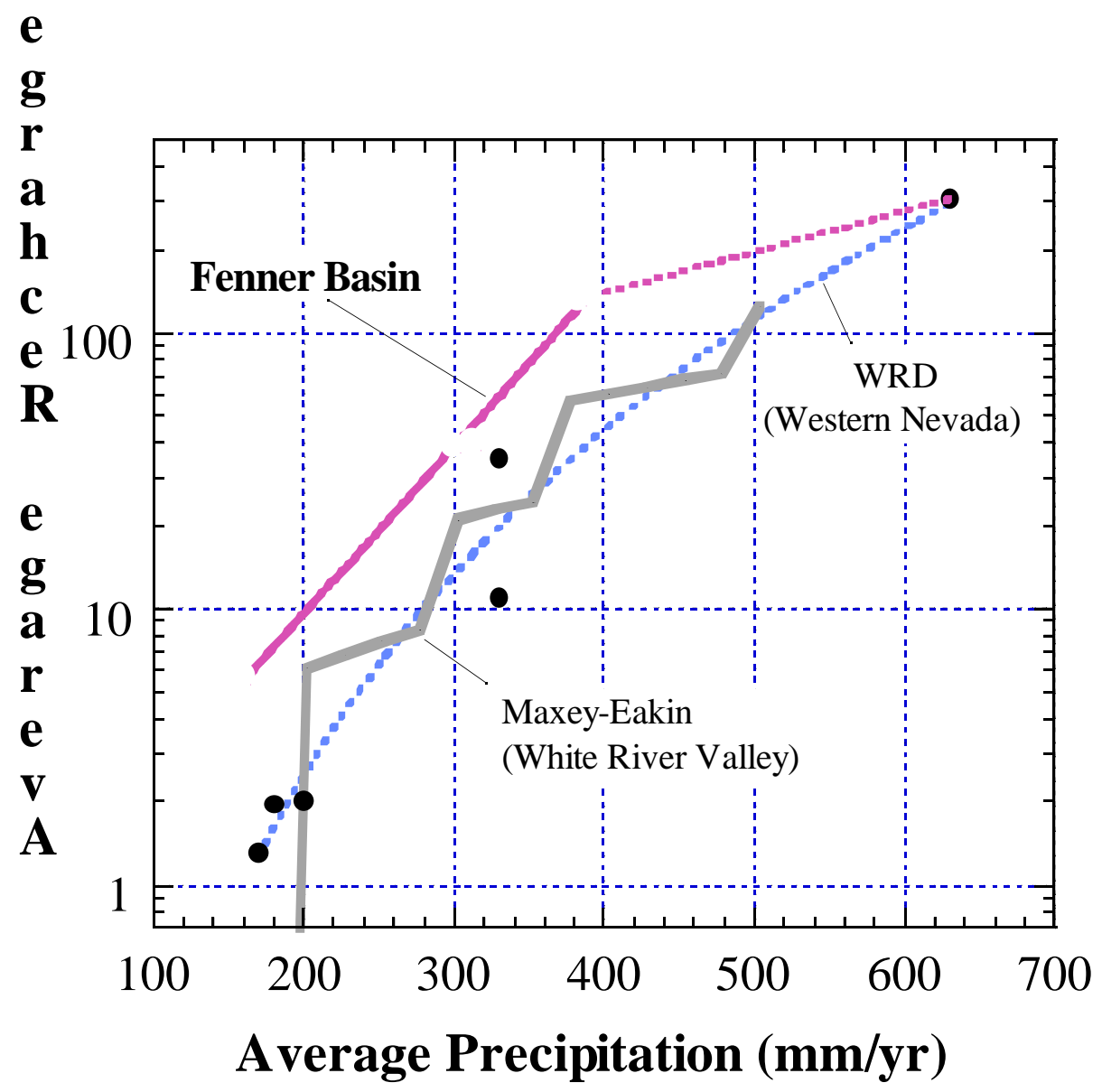

Figure 4. Maxey-Eakin curves used by LLNL, WRD, and Maxey-Eakin's original for the White River Valley, Nevada. 


\section{Appendix}

Calculating recharge rates at individual groundwater well sites requires an estimation of the annual precipitation accumulating in the recharge area of each well, the aquifer volume of groundwater flowing past each well, and a groundwater age. Dividing the aquifer volume by the groundwater age provides an annual replenishment rate. That rate is compared to the annual precipitation rate and used as a calibrating point for the MaxeyEakin curve. For a spring sample, the annual volume of spring discharge is simply compared to the annual precipitation rate accumulated in the spring's recharge area.

The recharge rates are estimates that require some assumptions about aquifer dimensions and recharge areas. In the following calculations, values for these parameters are chosen as to minimize the potential annual recharge. In doing so, the actual recharge rates may be higher than those calculated as final values.

\section{Example \#1}

The first example is from a groundwater well in the Providence Mts. The well is located in the upper part of Gold Valley $\left(35^{\circ} 5.9^{\prime} \mathrm{N}, 115^{\circ} 23.7^{\prime} \mathrm{W}\right)$. The well is reported to be completed in alluvium. This well was sampled and measured for radiocarbon age dating (Stephens and Associates, 1992). The radiocarbon abundance of the dissolved inorganic carbon had a "bomb-pulse" concentration (104 percent modern carbon), indicating that the groundwater was recharged less than 40 years ago. Bomb-pulse radiocarbon occurs in young groundwater due to surface testing of nuclear weapons, which injected an abnormal amount of radiocarbon into our atmosphere in the early 1960's.

This well has an estimated maximum recharge area of $12.9 \mathrm{~km}^{2}\left(5 \mathrm{mi}^{2}\right)$. The mean elevation of the recharge area is $1650 \mathrm{~m}(5400 \mathrm{ft})$, and the annual precipitation is estimated between $259 \mathrm{~mm} / \mathrm{yr}(10.3 \mathrm{in} / \mathrm{yr})$ and $365 \mathrm{~mm} / \mathrm{yr}(14.5 \mathrm{in} / \mathrm{yr})$, based on precipitationelevation curves (Fig. 3). Therefore, the total annual precipitation accumulating in the recharge area is 2708 to 3817 acre- $\mathrm{ft}\left(3.3\right.$ to $\left.4.7 \times 10^{6} \mathrm{~m}^{3}\right)$. We assume a minimum aquifer depth of $15 \mathrm{~m}(\sim 50 \mathrm{ft})$, a mean porosity of $10 \%$, and a groundwater age of 40 years. This results in an annual average recharge to the aquifer of 392 acre-ft $\left(4.8 \times 10^{5} \mathrm{~m}^{3}\right)$. Dividing this into the annual precipitation suggests that on average 10 to $15 \%$ of the annual precipitation recharges this area. This is equivalent to $40.3 \mathrm{~mm} / \mathrm{yr}(1.6 \mathrm{in} / \mathrm{yr})$.

\section{Example \#2}

The second example is a well sampled by LLNL February 3, 2000 in Round Valley (Mid Hills area; $35^{\circ} 08^{\prime} 52.5^{\prime \prime}, 115^{\circ} 21^{\prime} 28.8^{\prime \prime}$; NE,SW1/4 sec3 T12N R15E). This well also had a bomb-pulse radiocarbon value (113 percent modern carbon). The well also had bombpulse tritium $(16.7 \mathrm{pCi} / \mathrm{L})$ originating from post-1963 precipitation. Its maximum recharge area is $\sim 11.7 \mathrm{~km}^{2}\left(4.5 \mathrm{mi}^{2}\right)$. The mean elevation is $\sim 1600 \mathrm{~m}(5249 \mathrm{ft})$, and a mean annual precipitation rate ranges from 251 to $346 \mathrm{~mm} / \mathrm{yr}$ ( 10 to $13.7 \mathrm{in} / \mathrm{yr}$ ). Assuming the same aquifer parameters and groundwater age as the first example, the calculated annual recharge rate is 11 to $15 \%$ of the annual precipitation, or $40 \mathrm{~mm} / \mathrm{yr}$. This is nearly identical to the previous example. 


\section{Example \#3}

The third example is from the New York Mountains and a well located at the southern end of Caruthers Canyon ( $\left.35^{\circ} 13^{\prime} 33.7^{\prime \prime} ; 115^{\circ} 17^{\prime} 58.3^{\prime \prime}\right)$. Technically, Caruthers Canyon does not recharge the Fenner groundwater basin, but rather is thought to flow east towards the Colorado River. However, very similar canyons to the west in the New York Mountains (e.g. Fourth of July Canyon) provide recharge areas to the Fenner Basin. The well in Caruthers Canyon was sampled by LLNL February 3, 2000. This well also had bomb-pulse tritium $(18.2 \mathrm{pCi} / \mathrm{L})$, indicating recharge less than 40 years ago.

The recharge area for this well is $8.9 \mathrm{~km}^{2}\left(3.45 \mathrm{mi}^{2}\right)$. The mean elevation is estimated at $1875 \mathrm{~m}(6150 \mathrm{ft})$. Estimated annual precipitation is between 300 and $467 \mathrm{~mm} / \mathrm{yr}$ (11.9 to $18.5 \mathrm{in} / \mathrm{yr}$ ). This is equivalent to an annual accumulated precipitation in the recharge area between 2.7 and $4.2 \times 10^{6} \mathrm{~m}^{3} / \mathrm{yr}$.

The well purportedly is completed 350 feet $(107 \mathrm{~m})$ below ground surface (Gary Overson, personal communication). It is assumed that the mean aquifer depth over the recharge area is $40 \mathrm{~m}$, and has a mean porosity of $10 \%$. This suggests an aquifer volume of $35.6 \times 10^{6} \mathrm{~m}^{3}$. Dividing this volume by 40 years, suggests an annual recharge of $0.89 \times 10^{6} \mathrm{~m}^{3} / \mathrm{yr}$. Comparing this annual recharge to the accumulated precipitation, a suggested total of 21 to $33 \%$ of annual precipitation is recharged.

\section{Example \#4}

The fourth example is from Bonanza spring located on the southeastern side of the Clipper Range (NW,NW1/4 sec22 T7N R15E, Castle Dome, Calif 7.5 USGS Quad). This spring discharges at $640 \mathrm{~m}$ and has a maximum potential recharge area of about $15.5 \mathrm{~km}^{2}$ $\left(6 \mathrm{mi}^{2}\right)$ in the Clipper Range. This recharge area has an elevation range between 640 and $1100 \mathrm{~m}$. LLNL sampled this spring February 2, 2000. It was discharging at 0.1 cubic foot per second (cfs; $0.17 \mathrm{~m}^{3}$ per minute). The discharge was perennial and supported a maturely vegetated wetland extending at least $1.5 \mathrm{~km}$ downstream of the spring immersion point.

Assuming a sustained flow of $0.1 \mathrm{cfs}$ annually, we calculate a total annual discharge from Bonanza spring of 71 acre- $\mathrm{ft}\left(87,577 \mathrm{~m}^{3}\right)$. The recharge area averages $\sim 900 \mathrm{~m}$ in elevation. The annual average precipitation rate is calculated to be $160 \mathrm{~mm} / \mathrm{yr}$. This is a total accumulated precipitation volume of $\sim 2,139,000 \mathrm{~m}^{3}$, or 1734 acre-ft per year. The ratio of spring flow to annual precipitation in the recharge area indicates that the recharge rate for Bonanza spring is $4 \%$ of annual precipitation, or $5.5 \mathrm{~mm} / \mathrm{yr}$. 